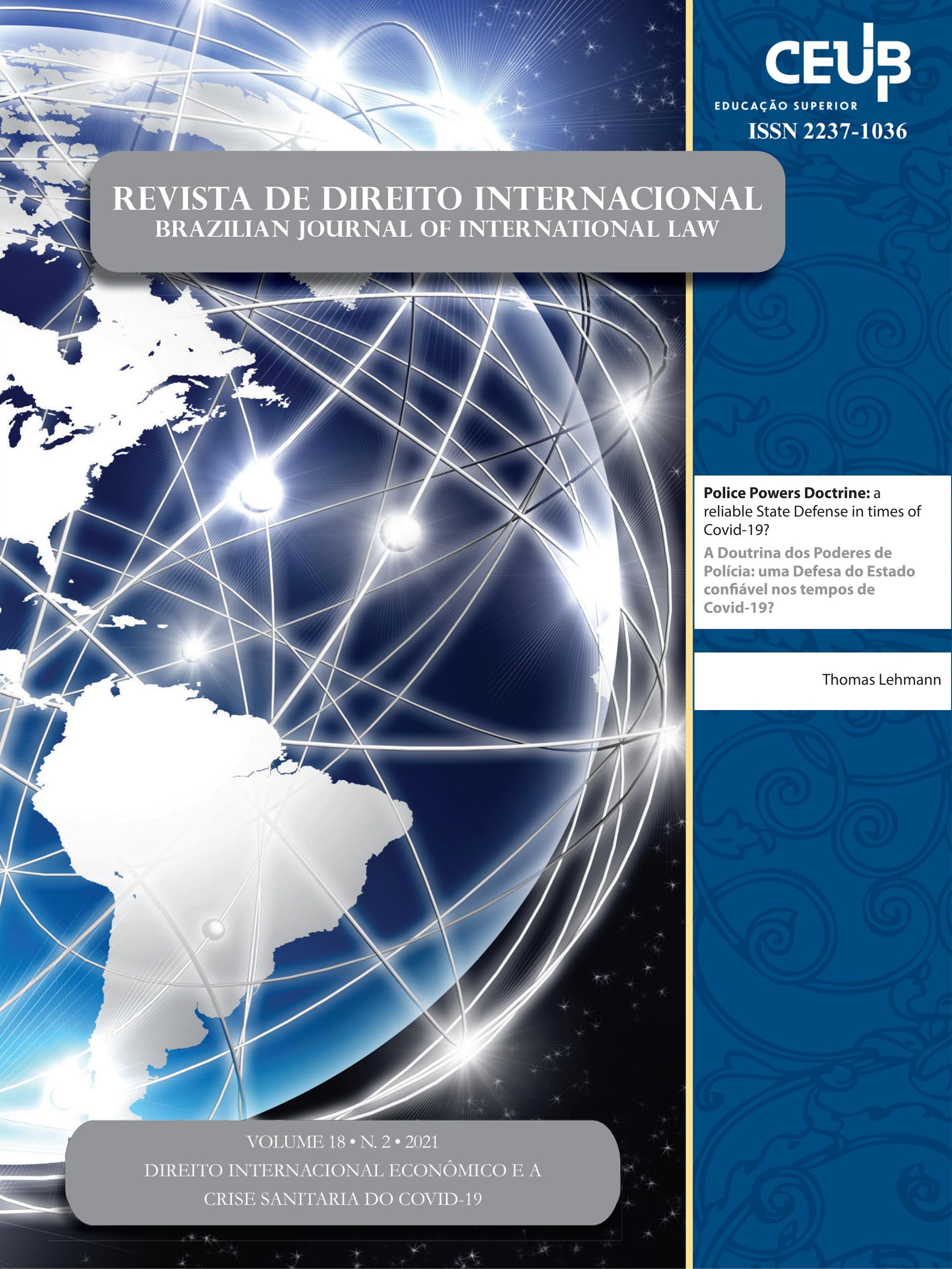




\section{Sumário}

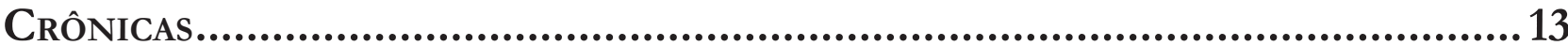

REIMAgining INTERNATIONAL RELATIONS TEACHING DURING (AND AFTER) COVID-19 ........15 Magdalena Bas

Dossiê Temático: Direito Internacional Econômico e a Crise sanitaria Do COVID-19 (INTERNATIONAL ECONOMic LaW AND THE COVID-19 SANITARY CRISIS) 19

Some QUESTIONS ABOUt INTERNATIONAL ECONOMic LAW RAISED DURING THE PANDEMIC .....21 Hervé Ascensio

International Economic LaW and the COVID-19 Sanitary Crisis: An Introduction 27 Julien Chaisse

TransparênCIA E COOPERAÇão REgUlatóRIA No COMÉRCIO INTERNACIONAL DE PRODUTOS MÉDicos PaRa a COVID-19: uMa ANÁlISE da ATUAÇão INSTITUCIONAL DA OMC E DAS NOTIFICAÇõES do Brasil EM OBSERVÂNCIA AOS ACordos TBT E SPS .35

Magali Favaretto Prieto Fernandes e Michelle Ratton Sanchez Badin

O DEVER HUMANO DE PROMOÇÃo DA SAÚDE: A AVIAÇÃo COMERCIAL INTERNACIONAL EM PERÍODOS DE CALAMIDADE SANITÁRIA E DO RETORNO À NORMALIDADE .56

Thiago de Oliveira Frizera, Luisa Cortat Simonetti Gonçalves e Adriano Sant'Ana Pedra

Police Powers Doctrine: a reliable State Defense in times of Covid-19?.... .73 Thomas Lehmann

A inexistênCia do Controle preventivo legislativo de Convencionalidade da Medida Provisória n. ${ }^{\circ} 936 / 2020$ .91

Danilo Garnica Simini, Gabriel Carvalho Moreira e Rafaela Souza Machado 
A Critical analysis of the implications of Covid-19 on piracy off the Nigerian COAST

Kalu Kingsley Anele

The COVID-19 PANDEMIC AS AN IMPELlER FOR THE AGgRAVATION OF MARINE PLASTIC POLLUTION AND ECONOMIC CRISIS: THE REVERSE EFFECT OF HEALTH PROTECTION MEASURES ON HUMAN LIVES 135

Adriana Isabelle Barbosa Lima Sá Leitão e Tarin Cristino Frota Mont’Alverne

Artigos sobre outros temas

O Direito Internacional Humanitário nos Pareceres Consultivos da Corte Internacional de Justiça: uma Conjugação de Perspectivas Utópicas e Apologéticas 156

Talis Prado Pinto Junior e Arthur Roberto Capella Giannattasio

Contesting immunities in the International Criminal Court: an analysis of the RUlings of the Pre-Trial Chambers and the Appeals Chamber in Al Bashir Case and its OUTCOMES. 171

Luisa Giannini e Roberto Vilchez Yamato

Rumo à Profissionalização da Prevenção de Controvérsias nos Acordos de CooperaÇão e Facilitação de InVEstimentos (ACFIs) do Brasil? 191

Nitish Monebhurrun e Leonardo Vieira Arruda Achtschin

THE PREVENTIVE CHARACTER OF DISASTER LAW: TAX INCENTIVES IN ENVIRONMENTAL, SOCIAL, AND GOVERNANCE (ESG) INVESTMENTS AS A RISK MITIGATION MECHANISM 212

Daniel Dela Coleta Eisaqui e Deilton Ribeiro Brasil

A URGÊNCIA DE UM MODELO DE GOVERNANÇA INTERNACIONAL DA ÁGUA: ELEMENTOS PARA A DISCUSSÃO

José Irivaldo Alves Oliveira Silva

O FIM DA HIERARQUIA SUPRALEgAL DOS TRATADOS INTERNACIONAIS: ANÁLISE DA ADI N.O 5.543/2020-DF: À luZ dA TeOria ARgumentativa de Neil Maccormick. 
Os DIREITOS HUMANOS FRENTE À NORMATIVIDADE “IMPERIAL" E A RESPONSABILIDADE DAS EMPRESAS TRANSNACIONAIS POR VIOLAÇÃO AOS DIREITOS HUMANOS NA ERA DO “IMPÉRIO” 280

Fernando Hoffmam e Jose Luis Bolzan de Morais

O RECONHECIMENTO FACIAL NAS SMART CITIES E A GARANTIA DOS DIREITOS À PRIVACIDADE E À PROTEÇÃO DE DADOS PESSOAIS.. 302

Diogo Dal Magro e Vinícius Borges Fortes

O DESENVOLVIMENTO HISTÓRICO DA PROSCRIÇÃo DO DESAPARECIMENTO FORÇADO DE PESSOAS E sua fenomenologia no Direito Penal Internacional e no Direito Internacional dos Direitos Humanos

Marcus Vinícius Xavier de Oliveira

CONSTITUCIONALISMO COOPERATIVO GLOBAL E DIREITO INTERNACIONAL PRIVADO: INSTRUMENTOS PARA UMA GOVERNANÇA DE DIREITO TRANSNACIONAL NA INTEGRAÇÃO. 362

Anderson Vichinkeski Teixeira, Roberto Correia da Silva Gomes Caldas e Luciane Klein Vieira

Proteção da inovação pela aplicaÇão do Direito da ConcorrênCia da União Europeia: ANÁLISE DA INDÚSTRIA FARMACÊUTICA.

Pablo Leurquin 


\title{
Police Powers Doctrine: a reliable State Defense in times of Covid-19?*
}

\section{A Doutrina dos Poderes de Polícia: uma Defesa do Estado confiável nos tempos de Covid-19?}

Thomas Lehmann**

\begin{abstract}
As measures taken against the threats of Coronavirus to the public health affect investments in South America and internationally, states are looking for defenses under international law to counter potential Investor-State claims. This article explores whether the Police Powers Doctrine could justify the policy measures taken to protect the public health during the Covid-19 sanitary crisis and avoid the payment of compensation for alleged indirect expropriations. The analysis will first lay out the general application of Police Powers Doctrine under international investment law. To do so, it will mainly investigate the interpretation of the Doctrine in cases relating to the protection of public health. Finally, it will assess the strength of the Doctrine in defending general policy measures taken during the Covid-19 sanitary crisis. The paper argues that, while most measures should qualify under the Police Powers Doctrine, arbitral tribunals might examine additional conditions to accord their legal qualification of an exercise of police powers with the specific facts of a case.
\end{abstract}

Keywords: Police Powers Doctrine; Public Health; State Defense; Covid-19; Public Interest.

\section{Resumo}

Como as medidas tomadas contra as ameaças do Covid-19 à saúde pública afetam os investimentos na América do Sul como também nas demais regiões, os Estados estão procurando por defesas sob o direito internacional para conter as potenciais reclamações dos investidores contra os Estados anfitriões. Este artigo explora se a doutrina dos Poderes da Polícia poderia justificar as medidas políticas tomadas para proteger a saúde pública durante a crise sanitária da Covid-19 e evitar o pagamento de indenizações por supostas desapropriações indiretas. A análise apresentará primeiramente a aplicação geral da Doutrina dos Poderes da Polícia no direito internacional de investimento. Para tanto, investigará principalmente a interpretação da Doutrina em casos relativos à proteção da saúde pública. Por fim, avaliará a força da Doutrina na defesa de medidas de política geral tomadas durante a crise sanitária da Covid-19. O artigo argumenta que, embora a maioria das medidas deva se enquadrar na Doutrina dos Poderes de Polícia, os tribunais

** PhD-candidate at Queen Mary University of London, affiliated to the Center for Commercial Law Studies.

Email: t.g.p.lehmann@qmul.ac.uk

* Recebido em 05/04/2020 Aprovado em 05/07/2021 
arbitrais podem examinar as condições adicionais para conferir sua qualificação legal para o exercício dos poderes de polícia com os fatos específicos de um caso.

Palavras-chave: poder de polícia, saúde pública, defesa do Estado, Covid-19

\section{Introduction}

Nationalisation, compelling production, stay-at-home policies, workplace closures, public events cancellations, restrictions on gatherings, restriction on internal and international movement ${ }^{1}$ - the containment measures adopted by States to counter the spread of the Covid-19 pandemic have had a significant impact on economic activity and foreign investments. According to a recent study by the International Monetary Fund, the containment measures alone led to an estimated loss of about 15-percent in industrial production over a 30 day period following their implementation. ${ }^{2}$

With important number of public health measures affecting industrial activity and foreign investments ${ }^{3}$ in South America ${ }^{4}$ and internationally, ${ }^{5}$ the field of International Investment Law could see rising numbers of treaty-based investment claims. This threat has led several non-governmental organisations to call for a memorandum on claims relating to pandemic instigated measures. ${ }^{6}$ The Columbia Center for Sustainable

\footnotetext{
1 BLAVATNIK SCHOOL OF GOVERNMENT; UNIVERSITY OF OXFORD. Coronavirus Government Response Tracker. Mar. 2021. Available in: https://www.bsg.ox.ac.uk/research/researchprojects/covid-19-government-response-tracker Accessed on: 31 Mar. 2021.

2 INTERNATIONAL MONETARY FUND. 'The Economic Effects of COVID-19 Containment Measures' IMF Working Papers No. 20/158. Jul. 2020. Available at: https://www.imf.org/en/Publications/WP/Issues/2020/08/07/The-Economic-Effects-of-COVID-19-Containment-Measures-49571 Accessed on: 31 Mar. 2021.

3 SANDERSON, Cosmo, Peru warned of potential ICSID claims over covid-19 measures. Latin Lawyer, Apr 2020. Available at: https://latinlawyer.com/article/1225491/peru-warned-of-potentialicsid-claims-over-covid-19-measures Accessed on: 31 Mar. 2021.

4 GONZALES, Elizabeth et al. The Coronavirus in Latin America. America Society Council of the Americas, Feb. 2021. Available at: https://www.as-coa.org/articles/coronavirus-latin-america Accessed on: 31 Mar. 2021.

5 UNCTAD INVESTMENT POLICY HUB. Investment Policy Monitor: Special Issue - Investment Policy Responses to the COVID-19 Pandemic. May 2020. Available at: https://unctad.org/system/files/official-document/diaepcbinf2020d3_en.pdf Accessed on: 31 Mar. 2021.

6 UNCTAD INVESTMENT POLICY HUB. Investment Policy
}

Investment has published a call for a "Moratorium" on ISDS disputes emanating from the pandemic. It argued that ISDS awards can "represent sizable percentages of governments' budgets" and that the "necessary business closures and other emergency responses will create unprecedented changes in the business environment that will likely trigger a massive number of unjustified claims (for) the loss of excepted profits." Similarly, the International Institute for Sustainable Development has called governments to either suspend the application of ISDS claims for all pandemic-related measures or clarify how international law defenses would pertain for this "extraordinary" situation. ${ }^{8}$ Finally, the African Union has produced a declaration on the risks of investor-State arbitration relating to COVID-19 measures.

In this context, States are looking for doctrines that would avoid their liability towards foreign Investors in potential Investment treaties-based claims on the ground of expropriation. This article investigates whether the Police Powers Doctrine may safeguard the State's right to regulate in protection of the public health during the Covid-19 era. While scholars have generally focused on the human rights implication of the Covid-19 in international investment law, ${ }^{9}$ this paper will analyse whether a defense can protect legitimate measures adopted by States. This paper will thus focus on the Police Powers Doctrine applied to the indirect expropriation standard under international investment law.

Police Powers Doctrine (also 'Doctrine'), states that a measure considered part of the state's Police Powers and resulting in substantial loss of asset does not constitute indirect expropriation, and, accordingly, does not

Monitor: Special Issue - Investment Policy Responses to the COVID-19 Pandemic. May 2020. Available at: https://unctad.org/system/files/official-document/diaepcbinf2020d3_en.pdf Accessed on: 31 Mar. 2021.

7 COLUMBIA CENTRE ON SUSTAINABLE INVESTMENT. Call for ISDS Moratorium During COVID-19 Crisis and Response. May 2020. Available at: http://ccsi.columbia.edu/2020/05/05/ isds-moratorium-during-covid-19/ Accessed on: 31 Mar. 2021.

8 BERNASCONI-OSTERWALDER, Nathalie; BREWIN, Sarah; MAINA, Nyaguthii. Commentary: Protecting Against Investor-State Claims Amidst COVID-19: A call to action for governments. IISD, April 2020. Available at: https://www.iisd.org/system/files/publications/investor-state-claims-covid-19.pdf Accessed on: 31 Mar. 2021.

9 DIAMOND, Nicholas; DUGGAL, Kabir. 2020 in Review: The Pandemic, Investment Treaty Arbitration, and Human Rights. Kluwer Arbitration Blog. Jan. 2021. Available at: http://arbitrationblog. kluwerarbitration.com/2021/01/23/2020-in-review-the-pandemicinvestment-treaty-arbitration-and-human-rights/ Accessed on: 31 Mar. 2021. 
give rise to an obligation to compensate. ${ }^{10}$ It allows the State to regulate, and to avoid its liability if its measures meet specific conditions. The word "police" originally

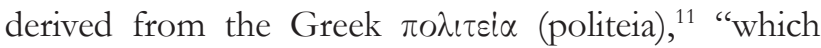
properly signified the policy of the civil government", ${ }^{12}$ refers to a liberal concept devised in Europe and later in the United States by philosophers of a natural law philosophy. ${ }^{13}$ The concept grants the States a right to regulate within a specific scope and in accordance with significant requirements, such as public interest, good faith, non-discrimination, reasonableness or proportionality, and two remainder subject to less contentious interpretation in the assessment of an indirect expropriation: legitimate expectations and due process.

The interpretation of the Doctrine constitutes nevertheless an obscure point of law. The integration, scope, requirements and threshold are constantly disputed in the case-law and scholarly opinions. This paper aims at understanding these very points of disputes among arbitral tribunals and demonstrates that the Police Powers Doctrine is applicable to potential disputes arising from the adoption of Covid-19 measures by States. It is further argued that the recognition of the Doctrine's applicability to measures during the pandemic has the potential to raise the legitimacy of the international investment law altogether.

\section{The concept and integration of the Police Powers Doctrine in International Investment Law}

In the field of international investment arbitration, where lawyers permanently try to order chaos into

\footnotetext{
10 TITI, Catherine. The Evolution of Substantive Investment Protections in Recent Trade and Investment Treaties, 2018. Available at: https://e15initiative.org/wp-content/uploads/2015/09/ ictsd_-_the_evolution_of_substantive_investment_protections_in_ recent_trade_and_investment_treaties_-_titi.pdf Accessed on 31 March 2021.

11 TITI, Catherine. Police Powers Doctrine and International Investment Law. In: FONTANELLI Filippo; GATTINI Andrea; TANZI Attila (eds.). General Principles of Law and International Investment Arbitration. Leiden: Brill, 2018. p.323-343.

12 SMITH Adam. Lectures on Justice, Police, Revenue and Arms, delivered in the University of Glasgow by Adam Smith: Reported by a Student in 1763 and edited with an Introduction and notes by Edwin Cannan. Oxford: Clarendon Press, 1869.

13 LEGARRE, Santiago. The Historical Background of the Police Power. University of Pennsylvania Journal of Constitutional Law, Philadelphia, v.9, p.745-796, Feb. 2007.
}

harmony,${ }^{14}$ Police Powers Doctrine appears as a fluid and elusive concept engendering disagreement, appearing in the assessment of emergency measures taken against an economic crisis, ${ }^{15}$ as well as the regulation of public utilities. ${ }^{16}$

In general, the Doctrine is understood in the case-law as a form of legitimate expression of the State's customary right to regulate. ${ }^{17}$ The right to regulate derives from the concept of State's sovereignty. This right has been clearly recognised in 2009 by the International Court of Justice. ${ }^{18}$ In the case Costa Rica v Nicaragua, the Court gave legal substance to the concept of regulation and the State's intention in the assessment of a regulatory measure. Additionally, the judges provided the protection of the environment with the status of one of the public purpose objectives that a State may legitimately pursue, even though the protection of the environment stood beyond the expectations of both Parties at the time they ratified a Treaty. ${ }^{19}$

14 GAILLARD, Emmanuel. 2018 Lalive Lecture "The Myth of Harmony in International Arbitration". ICSID Review - Foreign Investment Law Journal, Oxford, v. 34, n.3, p. 553-568, Apr. 2018.

15 CMS Gas Transmission Co v Argentina (Award) (ICSID Arbitral Tribunal, Case No. ARB/01/8, 12 May 2005); LG\&E Energy Corp, LG\&E Capital Corp, LG\&E International Inc v Argentina (Decision on Liability) (ICSID Arbitral Tribunal, Case No. ARB/02/1, 3 October 2006); Sempra Energy International v Argentina (Award) (ICSID Arbitral Tribunal, Case No. ARB/02/16, 28 September 2007); Enron Corp and Ponderosa Assets, LP v Argentina (Award) (ICSID Arbitral Tribunal, Case No. ARB/01/3, 22 May 2007); BG Group ple v Argentina (Final Award) (UNCITRAL Arbitral Tribunal, 24 December 2007); Continental Casualty Co v Argentina (Award) (ICSID Arbitral Tribunal, Case No. ARB/03/9, 5 September 2008); National Grid plc v Argentina (Award) (UNCITRAL Arbitral Tribunal, 3 November 2008); Suez, Sociedad General de Aguas de Barcelona SA, InterAguas Servicios Integrales del Aguas $S A v$ Argentina (Award) (ICSID Arbitral Tribunal, Case No. ARB/03/17, 30 July 2010); Daimler Financial Services AGv Argentina (Award) (ICSID Arbitral Tribunal, Case No. ARB/05/1, 22 October 2012); Poitova and ISTROK4PITAL SE v Hellenic Republic (Award) (ICSID Arbitral Tribunal, Case No. ARB/I13/8, 9 April 2015); Cyprus Popular Bank Public Co Ltd v Hellenic Republic (ICSID Arbitral Tribunal, Case No. ARB/14/16).

16 Biwater Gauff (Tanzania) Ltd v Tanzania (Award) (ICSID Arbitral Tribunal, Case No. ARB/05/22, 24 July 2004); Aguas del Tunari $S A v$ Bolivia (Decision on Respondents Objections to Jurisdiction) (ICSID Arbitral Tribunal, Case No. ARB/02/3, 21 October 2005).

17 PELLET, Alain. Police Powers of the State's Right to Regulate. In: KINNEAR, Meg; FISCHER, Geraldine (eds). Building International Investment Law: The First 50 Years of ICSID. Alphen aan den Rijn, Wolters Kluwer, Dec. 2015. p. 447-462.

18 Dispute regarding Navigational and Related Rights (Costa Ricav Nicaragua), International Court of Justice, Judgement Report of 13 July 2009, p. 40, para. 85 « le Nicaragua jouit en tant que souverain d'un pouvoir entier de réglementation».

19 Dispute regarding Navigational and Related Rights (Costa Ricav Nicaragua), International Court of Justice, Judgement Report of 13 
Most recently, the Doctrine has been recognized in the Philipp Morris v Uruguay award as part of international customary law. ${ }^{20}$ In Philip Morris v Uruguay, the tribunal found that certain anti-smoking measures taken by Uruguay "with a view to protect public health in fulfilment of its national and international obligations" were an "effective means to protect public health." The tribunal concluded that the measures were a "valid exercise by Uruguay of its police powers for the protection of public health" and, as such, did not constitute a breach of Uruguay's international obligations.

The Doctrine is however subject to different interpretations as to its scope, integration, customary status, and requirements. ${ }^{21}$ Tribunals have held divergent or contradictory rules and interpreted differently the scope of the customary law.

\subsection{Scope, sources and customary nature of the Police Powers Doctrine}

In 1941, John Herz stated that where measures indirectly interfere with individual property rights "it may often be very difficult to decide whether or not... the limits of usual interference have been reached or transgressed". ${ }^{22}$ Historically two views of scope oppose themselves. Under the broader view of Police Powers Doctrine, it can include morality, public health and the environment. ${ }^{23}$ Under the much stricter view the Doctrine limits itself to tax, crime and the maintenance of public order. ${ }^{24}$

July 2009. para. 89.

20 Philip Morris Brands Sárl, Philip Morris Products SA and Abal Hermanos SA v Oriental Republic of Uruguay, ICSID Case No. ARB/10/7, Award, 8 July 2016, para.307.

21 WAELDE, Thomas; KOLO, Abba. Environmental Regulation, Investment Protection and "Regulatory Taking" in International Law. International and Comparative Law Quarterly, Cambridge, v.50, n.4, p.811-848, Oct. 2008.

22 HERZ, John. Expropriation of Foreign Property. The American Journal of International Law, Cambridge, v. 35, p.243-262, Apr. 1941.

23 GUDOFSKY, Jason. Shedding Light on Article 1110 of the North American Free Trade Agreement (NAFTA) Concerning Expropriations: An Environmental Case Study. Northwestern Journal of International Law and Business, Chicago, v.21, n.1, p.243-316, Jan. 2000; See also: CHRISTIE, George. What constitutes a Taking of Property Under International Law? British Yearbook of International Law, Oxford, v.38, p.307-338, 331-32, 1962.

24 BAUGHEN, Simon. Expropriation and Environmental Regulation: The lessons of NAFTA Chapter Eleven, Journal of Environmental Law, Oxford, v.18, n.2, p.207-228, Jan. 2006.
Even though the Saluka tribunal was once right in stating that: "International law has yet to identify comprehensively and definitively precisely what regulations are considered 'permissible' and 'commonly accepted' as falling within the police or regulatory power of States", 25 it is today clearly recognised that the protection of public health is part of the ambit of the Police Powers Doctrine, notably in view of the sources that explicitly refer to the protection of human health, contrarily to the protection of the environment.

Tribunals referring to the Police Powers Doctrine, commonly consider the following four sources: the 1961 Draft Convention on the International Responsibility of States for Injuries to Aliens' devised by Harvard Law School ('1961 Harvard Draft'); the third Restatement of the Foreign Relations Law of the United States of 1987 ('Restatement'); the OECD Report regarding the 'Indirect Expropriation' and the 'Right to Regulate' in International Investment Law of 2004 ('OECD Report'); and case-law. ${ }^{26}$ In 2016, the Tribunal in Philip Morris v. Uruguay observed that, since 2000, "a range of investment decisions have contributed to develop the scope, content and conditions of the State's police powers doctrine, anchoring it in international law". ${ }^{27}$

Whether the Police Powers Doctrine is part or not of international customary law is a crucial question. It is commonly accepted that no rule of precedence is recognized in international investment arbitration. However, international treaties are bound by an interpretation that is given by international customary law, as codified by the VCLT, article 31 (1)(c). International customary law is in this sense could be perceived as relevant when a case of expropriation and deprivation of the investment is searched under the articles of the IIA and its section "expropriation". Thus, it is crucial to understand what sources tribunals commonly refer to when stating that the Doctrine has evolved into a customary rule. $^{28}$

25 Saluka Investments BV v Czech Republic, UNCITRAL, Partial Award 17 March 2006. para. 262.

26 ZAMIR, Noam. The Police Powers doctrine in international investment law. Manchester Journal of International Economic Law, Manchester, v.14, n.3, p.318-337, Dec. 2017.

27 Philip Morris Brands Sárl, Philip Morris Products SA and Abal Hermanos $S A v$ Oriental Republic of Uruguay, ICSID Case No. ARB/10/7, Award, 8 July 2016. para. 295.

28 Philip Morris Brands Sárl, Philip Morris Products $S A$ and Abal Hermanos $S A v$ Oriental Republic of Uruguay, ICSID Case No. ARB/10/7, Award, 8 July 2016. para. 295. 
The customary nature law needs the demonstration of an opinio juris that stems both from civil and common law. ${ }^{29}$ The Doctrine of Police Powers seems to have existed in both models of reasoning. In common law, the Doctrine meant that the States were entitled to restrict private rights to ensure the development of health, morals, safety and environmental standards. ${ }^{30} \mathrm{In}$ civil law systems, the concepts of sic utere tuo ut alterum non leadas and Salus Publica suprema lew esto (public safety is the supreme law) ${ }^{31}$ could found a consensus around the Doctrine. However, comparative studies $^{32}$ relating to compensation of takings under public policies demonstrates that whether a private property was protected constitutionally (as in France for instance) ${ }^{33}$ or not, the amount of compensation is highly variable from countries to countries. ${ }^{34}$

Investor-States tribunals are divided in their approach of the Doctrine as customary international law. Already the Iran-US Claims Tribunal considered in the ${ }^{29}$ ZAMIR, Noam. The Police Powers doctrine in international in-
vestment law. Manchester Journal of International Economic Law, Man-
chester, v.14, n.3, p.318-337, Dec. 2017. 37. HERZ, John. Expropri-
ation of Foreign Property. The American Journal of International Law,
Cambridge, v. 35, p.243-262, Apr. 1941. 251 "There were always
certain cases in which state interference with private property was
not considered expropriation entailing an obligation to pay com-
pensation but a necessary act to safeguard public welfare: e.g., meas-
ures taken for reasons of police, that is, for the protection of public
health or security against internal or external danger."

30 GALVA, Jorge; ATCHISON Christopher; LEVEY Samuel. Public Health Strategy and the Police Powers of the State. Public Health Report, Washington D.C., v. 120, n.1, p. 20-27, 2005.

31 REYNOLDS Glenn; KOPEL David. The Evolving Police Power: Some Observations for a New Century. Hastings Constitutional Law Quarterly, San Fransisco, v.27, n.3, p. 511-538, Jan. 2000.

32 ALTERMAN, Rachelle; BALLA Evangelina. Takings International: A Comparative Perspective on Land Use Regulations and Compensation Rights. Chicago: American Bar Association Section of State and Local Government Law, 2010.

33 ALTERMAN, Rachelle; BALLA Evangelina. Takings International: A Comparative Perspective on Land Use Regulations and Compensation Rights. Chicago: American Bar Association Section of State and Local Government Law, 2010. p.30: "However, the Conseil has ruled that most types of land use regulations are outside the scope of the constitutional protection of property." See also the Preamble of the Constitution of the French Republic from 1958 cites the 'Declaration de Droits de l'Homme et du Citoyen' from 1789 that states in its Article 2: "The aim of all political association is the preservation of the natural and imprescriptible rights of man. These rights are liberty, property, security, and resistance to oppression."

34 ALTERMAN, Rachelle; BALLA Evangelina. Takings International: A Comparative Perspective on Land Use Regulations and Compensation Rights. Chicago: American Bar Association Section of State and Local Government Law, 2010.
Sedco case 1985 that it is "an accepted principle of international law that a State is not liable for an economic injury which is a consequence of bona fide 'regulation' within the accepted police power of states". ${ }^{35}$ Later on, S.D. Myers tribunal in its award claimed that the distinction between expropriation and regulation reduces the risk of complaints by Investors and allows the State to manage public affairs ${ }^{36}$ - even though regulation "could be subject of a legitimate expropriation claim". ${ }^{37}$ The Tecmed award elaborated further, considering that regulation affecting economic damage could be exempt from compensation. ${ }^{38}$

However, the Santa Elena case 2000 excluded the purpose of a measure and used the sole effect Doctrine to state that "no matter how laudable and beneficial to society as a whole $(. .$.$) where the property is expropria-$ ted, even for environmental purposes, whether domestic or international, the state's obligation to pay compensation remains." ${ }^{39}$ Following the same reasoning, Pope \& Talbot case rejected Canada's claim that non-discriminatory regulations were beyond the NAFTA section's on expropriation. ${ }^{40}$

In the Iran-US Claims Tribunal considered in the Sedco case 1985 that it is "an accepted principle of international law that a State is not liable for an economic injury which is a consequence of bona fide 'regulation' within the accepted police power of states". ${ }^{41}$ In the $S a$ -

35 Sedco Inc v. National Iranian Oil Co (1985) 9 Iran-US CTR 248, 275. 36 S.D. Myers, Inc. v Government of Canada, First Partial Award ("Merits Award"), 13 November 2000, para. 282: "the distinction between expropriation and regulation screens out most potential cases of complaints concerning economic intervention by a state and reduces the risk that governments will be subject to claims as they go about their business of managing public affairs.". See also S.D. Myers, para 263: "That determination must be made in the light of the high measure of deference that international law generally extends to the right of domestic authorities to regulate matters within their own borders."

37 S.D. Myers, Inc. v Government of Canada, First Partial Award ("Merits Award”), 13 November 2000. para. 282.

38 Técnicas Medioambientales Tecmed, S.A. v The United Mexican States, (Award) (ICSID Arbitral Tribunal, case No. ARB (AF)/00/02, 29 May 2003). para 119: “The principle that the State's exercise of its sovereign powers within the framework of its police power may cause economic damage to those subject to its powers as administrator without entitling them to any compensation whatsoever is undisputable."

39 Compañia del Desarrollo de Santa Elena SA v The Republic of Costa Rica, ICSID ARB/96/1, Final Award of 17 February 2000, para 76; Azurix v Argentina, Award, 14 July 2006, paras 71-72.

40 Pope \& Talbot v Government of Canada, UNCITRAL Interim Award, June 26, 2000, para 282.

41 Sedco Inc (n 34), 275. 
luka v Czech Republic, the tribunal considered the Police Powers Doctrine to be part of customary international law. ${ }^{42}$ The tribunal located the authority of the norm in three international instruments meant to represent the State's practice and scholarly opinion necessary to establish the customary nature of a rule. ${ }^{43}$ Similarly, the Philip Morris tribunal adopted the same sources to establish the customary nature of Police Powers Doctrine. ${ }^{44}$

The most recent take on the scope of Police Powers Doctrine acknowledged in the Magyar arbitral award, that a line of case law had been developed, consisting of "regulatory measures aimed at abating threats that the investor's activities may pose to public health, environment or public order. ${ }^{45}$ We could thus argue that the customary nature of the Doctrine is established.

\subsection{Integration of the Police Powers in the interpretation of international investment agreements}

Most international investment agreements are from an older generation, ${ }^{46}$ and do not include a direct reference to the Police Powers Doctrine. Thus, they do not provide an exemption for general policies aimed at protecting public health from findings of indirect expropriation on the ground of public interest. Before addressing the general requirements for the application of the Doctrine, it is therefore crucial to understand the process of integration of the doctrine by arbitrators

\footnotetext{
42 Saluka Investments BV v Czech Republic, UNCITRAL, Partial Award 17 March 2006. para. 256.

43 TITI, Catherine. Police Powers Doctrine and International Investment Law. In: FONTANELLI Filippo; GATTINI Andrea; TANZI Attila (eds.). General Principles of Law and International Investment Arbitration. Leiden: Brill, 2018. p.323-343.

${ }^{44}$ Philip Morris Brands Sárl, Philip Morris Products SA and Abal Hermanos $S A v$ Oriental Republic of Uruguay, ICSID Case No. ARB/10/7, Award, 8 July 2016.

${ }_{45}$ Magyar Farming v Hungary, Award, 13 November 2019, para. 302; The tribunal refers to the following cases Chemtura Corporation v Government of Canada, UNCITRAL, Award of 2 August 2010; Methanex Corporation v United States of America, UNCITRAL, Final Award on Jurisdiction and the Merits, 3 August 2005, RL-109; AWG Group Ltd. v The Argentine Republic, UNCITRAL, Decision on Liability, 30 July 2010; Philip Morris Brands Sárl, Philip Morris Products SA and Abal Hermanos $S A v$ Oriental Republic of Uruguay, ICSID Case No. ARB/10/7, Award, 8 July 2016.

46 TITI, Catharine. International Investment Law and the European Union: Towards a New Generation of International Investment Agreements. European Journal of International Law, Oxford, v.26, n.3, p.639-661, Aug. 2015
}

confronted with an Agreement that does not expressly refer to Police Powers Doctrine.

When assessing the existence of an expropriation and application of the Doctrine, arbitral tribunals are required to apply Article 31 of the Vienna Convention on the Law of Treaties (VCLT), which sets out the main interpretation principles of treaties. ${ }^{47}$ Article 31(3)(c) has been widely used by arbitral tribunals ${ }^{48}$ to include Police Powers Doctrine as a customary international law in their interpretation of clauses. However, other methods of reasoning provided by the VCLT could also be used to integrate extraneous rules. ${ }^{49}$ Customary international law could be implemented through the "ordinary meaning" under Article 31(1) or as "special" meaning under Article 31(4)..$^{50}$

The arbitral tribunals in Saluke and Philip Morris have referred implicitly and explicitly to the Article 31(3)(c) of the Vienna Convention on the Law of Treaties to assess the relevance of the Police Powers Doctrine. ${ }^{51}$ Thus, this article is a gateway for arbitral tribunals to bring extraneous rules into the dispute. ${ }^{52}$

The tribunal should follow the construction of Article 31(3)(c) and find out whether the following requirements are met: ${ }^{53}$ (a) whether there is 'a rule of

47 ASCENSIO, Hervé. Article 31 of the Vienna Conventions on the Law of Treaties and International Investment Law. ICSID Review, Oxford, v. 31, n.2, p.366-387, Jun. 2016.

48 The text of the Article 31(3)(c) of the Vienna Convention stipulates that: "There shall be taken into account, together with the context: (c) any relevant rules of international law applicable in the relations between the parties".

49 CHENG, Bin. General Principles of Law as applied by International Courts and Tribunals. Cambridge: Cambridge University Press, 2006.

50 PAPARINSKIS, Martin. Investment Treaty Interpretation and Customary Investment Law: Preliminary Remarks. In: BROWN, Chester; MILES, Kate (eds.). Evolution in Investment Treaty Law and Arbitration. Cambridge: Cambridge University Press, 2011. p. 65-78.

51 Saluka Investments BV v Czech Republic, UNCITRAL, Partial Award 17 March 2006. para. 254; Philip Morris Brands Sárl, Philip Morris Products $S A$ and Abal Hermanos SAv Oriental Republic of Uruguay, ICSID Case No. ARB/10/7, Award, 8 July 2016. para. 290; Veteran Petroleum Ltd $v$ The Russian Federation, UNCITRAL PCA Case No. $\square$ 2005-05/AA228, Interim Award, 30 November 2009, para 309; El Paso Energy International Company v Argentine Republic, ICSID Case No. ARB/03/15, Award of 31 October 2011, para 601-602.

52 ASCENSIO, Hervé. Article 31 of the Vienna Conventions on the Law of Treaties and International Investment Law. ICSID Review, Oxford, v. 31, n.2, p.366-387, Jun. 2016.

53 PAPARINSKIS, Martin. Investment Treaty Interpretation and Customary Investment Law: Preliminary Remarks. In: BROWN, Chester and MILES, Kate (eds.). Evolution in Investment Treaty 
international law"54; (b) whether this rule is "applicable in the relations between the parties" ${ }^{\prime 55}$; (c) if the rule is relevant ${ }^{56}$; (d) and if it is admissible in the process of interpretation. ${ }^{57}$ Some argue in addition that, to be admissible, the rule needs to be weighed in with the dispute at stake. ${ }^{58}$ These requirements are not explicitly described by arbitral tribunals in their awards, they offer nevertheless the stability tribunals should aim at when assessing an expropriation and using Article 31(3)(c).

Debate on the use of the Vienna Convention is endemic to international law. As we have broadly described, some argue that Article 31(1) on the ordinary meaning can be expended in order to take into account the purpose of police powers doctrine, others defend a textual approach to the Convention and warn before the systemic integration of norms through Article 31(3)(c).

This paper positions itself in an equilibrium, arguing that police powers doctrine should not be integrated through an extensive interpretation of the treaty's words (Article 31(1)), but only integrated through the reasoning when the treaty expressly refers to it, or when the measure at stake makes the use of the Doctrine relevant and necessary under Article 31(3)(c).

Law and Arbitration. Cambridge: Cambridge University Press, 2011. p. 65-78.

54 SIMMA, Bruno. Foreign Investment Arbitration: A Place for Human Rights. International and Comparative Law Quarterly, place, v. 60, n. 3, p.573-596, Jul. 2011.

55 RANJAN, Prabash. Police Powers, indirect expropriation in international investment law, and article 31(3)(c) of the VCLT: A critique of Philip Morris $v$ Uruguay. Asian Journal of International Law, place, v. 9, n. 1, p.98-124, Sep. 2019.

56 PAPARINSKIS, Martin. Investment Treaty Interpretation and Customary Investment Law: Preliminary Remarks. In: BROWN, Chester and MILES, Kate (eds.). Evolution in Investment Treaty Law and Arbitration. Cambridge: Cambridge University Press, 2011. p. 65-78.

57 PAPARINSKIS, Martin. Investment Treaty Interpretation and Customary Investment Law: Preliminary Remarks. In: BROWN, Chester and MILES, Kate (eds.). Evolution in Investment Treaty Law and Arbitration. Cambridge: Cambridge University Press, 2011. p. 65-78.

58 PAPARINSKIS, Martin. Investment Treaty Interpretation and Customary Investment Law: Preliminary Remarks. In: BROWN, Chester and MILES, Kate (eds.). Evolution in Investment Treaty Law and Arbitration. Cambridge: Cambridge University Press, 2011. p. 65-78.

\section{The disputed conditions and threshold for the application of the Doctrine}

After briefly assessing the integration through which arbitral tribunals can employ the Doctrine in their reasoning, we now turn to the general content and requirements of the Doctrine and the criteria that need to be fulfilled for a measure to qualify as an exercise of Police Powers.

\subsection{The requirements for a measure to qualify under the Doctrine}

A State measure would generally qualify as an exercise of police powers, under the most demanding requirements, only where it fulfils the requirements of public purpose, non-discrimination, and reasonableness or proportionality, with three remainders - legitimate expectations, good faith and due process being more self-explanatory and less contentious in regard of an indirect expropriation..$^{59}$

First and foremost, the measure must be enacted to pursue a public purpose, the purpose of protecting public's welfare. ${ }^{60}$ Defining this criterion for Police Powers Doctrine purposes is not clear-cut. The reason is that each State developed its own understanding of what a public purpose is, a definition that is often deeply rooted in domestic legal tradition. ${ }^{61}$

Earlier decisions sought to detail the exact content of the public purpose concept and of the good faith requirement. ${ }^{62}$ An example of this approach can be found in Feldman v Mexico. The tribunal held that: "governments must be free to act in the broader public interest through protection of the environment, new or modified tax regimes, the granting or

\footnotetext{
59 Methanex Corporation v United States of America, UNCITRAL, Final Award on Jurisdiction and the Merits, 3 August 2005, RL-109. para. 7; Chemtura Corporation v Government of Canada, UNCITRAL, Award of 2 August 2010. para. 266; Saluka Investments BV v Czech Republic, UNCITRAL, Partial Award 17 March 2006. para. 255.

${ }^{60}$ Marvin Roy Feldman Karpa v United Mexican States, ICSID Case No ARB(AF)/99/1, Award of 16 December 2002, [103]-[105].

${ }^{61}$ MARTINEZ-FragA, Pedro; REETZ, Ryan. Public Purpose in International Law, Rethinking Regulatory Sovereignty in the Global Era. New York: Cambridge University Press, 2015.

62 MITCHELL, Kate. Accommodating the Public Interest in International Investment Treaties: Police Powers, Expropriation and Treaty Interpretation. 2014. 121 f. Thesis (Masters) - MPhil, University of Oxford, Oxford, 2014.
} 
withdrawal of government subsidies, reductions or increases in tariff levels, imposition of zoning restrictions and the like."

For some scholars, the notion of public purpose should be defined with regards to the society's current standard of reasonably acceptable behavior. ${ }^{63}$ This however echoes the reference to international practices - such as international treaties and customs - to define the scope of the doctrine, while depriving it both from its legal coloration and its international nature. Prima facie, measures taken to counter the spread of a pandemic and protect public health, would easily constitute a consensus as to its qualification of a public purpose.

Second, to qualify as an exercise of police powers, the measure must be non-discriminatory. ${ }^{64}$ It must have the same effects on each affected investor, hence not targeting any particular investor. ${ }^{65}$ Some issues can however arise in relation to the definition of "targeting" of an investor. For example, in Chemtura, the measure was targeting one single pesticide, which did not prevent the tribunal to grant Canada the police powers protection.

Third, a disputed requirement pertains to whether the exercise of the PPD's can be affected by the concept of legitimate expectations. One strong evidence for the existence of legitimate expectation as a component of the PPD, is demonstrated by the Methanex award. The Tribunal stated that a measure may benefit from the defence of police powers "unless specific commitments had been given by the regulating government". ${ }^{66}$ Since, it has been put forth that in the case that a host state guarantees the maintenance of a stable regulatory environment, and an investor subsequently invests, that the investor will then acquire a more robust claim for indirect expropriation ${ }^{67}$. However, this feature may also

\footnotetext{
63 WAELDE, Thomas; KOLO, Abba. Environmental Regulation, Investment Protection and "Regulatory Taking" in International Law. International and Comparative Law Quarterly, Cambridge, v.50, n.4, p.811-848, Oct. 2008. p.827.

64 Saluka Investments BV v Czech Republic, UNCITRAL, Partial Award 17 March 2006.

${ }_{65}$ MITCHELL, Andrew D., HEATON, David, and HENCKELS, Caroline. Non-Discrimination and the Role of Regulatory Purpose in International Trade and Investment Law. Cheltenham: Edward Elgar, 2016.

${ }_{66}$ Methanex Corporation v United States of America, UNCITRAL, Final Award on Jurisdiction and the Merits, 3 August 2005, RL-109. para. 7.

${ }^{67}$ VIÑUALES, Jorge E. Sovereignty in Foreign Investment Law. In: DOUGLAS, Zachary, PAUWELYN, Joost, and VINUUALES, Jorge E. (eds). Foundations of International Investment Law. Ox-
}

be understood to the benefit of States. If an investor supplies capital in a sector where existing regulations are high and is expected to persist, then for the investor the chances of a successful claim for indirect expropriation may be reduced. ${ }^{68}$ Nevertheless, the absence of unanimity over the relevance of legitimate expectation to the PPD or indirect expropriation analysis retracts from the ability to draw any absolute conclusions. ${ }^{69}$ It remains equivocal whether this component specifically pertains to the functioning of the PPD, or rather a fragment of the general indirect expropriation claim. ${ }^{70}$

Fourth, the measure must be reasonable and/or proportional. The inherent vagueness of these two notions have led to significant differences in the assessment of tribunals. ${ }^{71}$ An unreasonable measure has been described as a regulation which is arbitrary, discriminatory, disproportionate, or entices other unfair conducts. ${ }^{72} \mathrm{It}$ has also been argued that a measure which substantially deprives an investor of its investment will necessarily be unreasonable, unless it relates to an inherently hazardous or immoral industry. ${ }^{73}$ Proportionality is assessed by weighing the damage incurred to the investor by the measure against the aims pursued by that measure. ${ }^{74}$ Thus, the importance of the protected public interest is key to determine whether the measure is proportional, with a public purpose of greater importance allowing for a more substantial infringement of investors' rights.

ford: Oxford University Press, 2014, Chapter 12, 340-342; HIGGINS, Rosalyn. The Taking of Property and the State: Recent Developments. Leiden: Martinus Nijhoff, 1982.

68 VIÑUALES, Jorge E. Sovereignty in Foreign Investment Law. In: DOUGLAS, Zachary, PAUWELYN, Joost, and VIÑUALES, Jorge E. (eds). Foundations of International Investment Law. Oxford: Oxford University Press, 2014, Chapter 12, 340-342; Methanex Corporation v United States of America, UNCITRAL, Final Award on Jurisdiction and the Merits, 3 August 2005, RL-109. para. 8-10.

69 VIÑUALES, Jorge E. Sovereignty in Foreign Investment Law. In: DOUGLAS, Zachary, PAUWELYN, Joost, and VIÑUALES, Jorge E. (eds). Foundations of International Investment Law. Oxford: Oxford University Press, 2014, Chapter 12, 340-342.

${ }^{70}$ HIGGINS, Rosalyn. The Taking of Property and the State: Recent Developments. Leiden: Martinus Nijhoff, 1982.

${ }^{71}$ Generation Ukraine Inc. v Ukraine, ICSID Case No. ARB/00/9, Award of 16 December 2003, [20]-[29]

72 El Paso Energy International Company v Argentine Republic, ICSID Case No. ARB/03/15, Award of 31 October 2011, [241].

73 MITCHELL, Kate. Accommodating the Public Interest In International Investment Treaties: Police Powers, Expropriation And Treaty Interpretation. 2014. 121 f. Thesis (Masters) - MPhil, University of Oxford, Oxford, 2014.

${ }^{74}$ LG\&E Energy Corp, LG\&E Capital Corp, and LG\&E International Inc $v$ The Argentine Republic (Decision on Liability) ICSID ARB/02/1 3 October 2006 at [195]. 
Tribunals will also take into account whether less interfering measures could have been used as an alternative. ${ }^{75}$ Following this requirement, the application of the doctrines becomes a fact-specific investigation, requiring tribunals to assess the nature importance of the problem addressed by the measure, the context in which it has been enacted. This point is further addressed bellow.

We described the general requirements put forth for the application of police powers doctrine. We now turn to the more specific assessment of the disputed threshold of application of the Doctrine.

\subsection{Divergent opinions on the threshold of application}

The versatility of decisions considering the threshold of the Doctrine show the level of inconsistency and lack of autonomy of the Doctrine. ${ }^{76}$ Indeed, while private law specialists expose a shift to a form of transnational private law governance through the usage of international customary law, ${ }^{77}$ the use of Police Powers outside of explicit treaty provisions gives rise to substantial questions when defining and applying the Doctrine. $^{78}$

Mainly, four different interpretations were applied in the assessment of the Police Powers Doctrine. ${ }^{79}$

First, the Methanex case emphasizes the role of public purpose in the enactment of the State's measure. The test adopted by the tribunal to determine whether

\footnotetext{
75 HENCKELS, Caroline. Indirect Expropriation and the Right to Regulate: Revisiting Proportionality Analysis and the Standard of Review in Investor-State Arbitration. Journal of International Economic Law, Oxford, v. 15, n.1, p. 223-255, Mar. 2012.

${ }^{76}$ ALVAREZ, José E. The search for Objectivity: The Use of Experts in Philip Morris v Uruguay. Journal of International Dispute Settlement, Oxford, v. 9, n. 3, p. 411-422, Apr. 2018. See also Philip Morris Brands Sarl, Philip Morris Products S.A. and Abal Hermanos S. A. v Oriental Republic of Uruguay, ICSID Case No. ARB/10/7, Concurring and Dissenting Opinion Co-Arbitrator, para.4-5.

77 HARRIS, Troy L. Customary International Arbitration Law. American Review of International Arbitration, New York, v. 24, n. 2, p. 245-270, Aug. 2013.

78 PELLET, Alain. Police Powers of the State's Right to Regulate. In: KINNEAR, Meg; FISCHER, Geraldine (eds). Building International Investment Law: The First 50 Years of ICSID. Alphen aan den Rijn, Wolters Kluwer, Dec. 2015. p. 447-462. p.449.

79 RANJAN, Prabash. Police Powers, indirect expropriation in international investment law, and article 31(3)(c) of the VCLT: A critique of Philip Morris v Uruguay. Asian Journal of International Law, Cambridge, v. 9, n. 1, p.98-124, Sep. 2019.
}

the measure amounts to expropriation - a lawful, non-compensable regulation - was primarily based on the purpose, the absence of discriminatory treatment and due process. ${ }^{80}$ The limit to this exception are the potential specific commitments given by the State to the Investor that it would refrain from adopting the measure at stake. This rule is the lowest standard of review applied by an arbitral tribunal, since no mention is made of the measure needing to be "reasonable" or "proportional". The Methanex understanding of Police Powers Doctrine leads to rule out the consideration for "economic damage" to the Investor and the "quantum of economic harm caused to foreign investment". ${ }^{81}$

Second, in the Saluka case, the tribunal referred to the legitimate "exercise of regulatory actions aimed at maintaining public order" and pointed out that this right justified the deprivation of the investor's assets. The tribunal was faced with the interpretation of the expropriation clause found in Article 5 of the BIT between the Netherlands and the Czech Republic, titled "deprivation". Referring to the interpretation clause under Article 31(3)(c) of the VCLT, the tribunal held that the term "deprivation" given in Article 5 made the import of the customary international law relevant. ${ }^{82}$ In applying the Police Powers Doctrine, the tribunal stated that States are not liable to pay compensation to a foreign investor if their measures are bona fide regulations aimed at general welfare taken without discrimination. ${ }^{83}$ The Tribunal links the "normal exercise of the state's regulatory power with the exclusion of the expropriation claim, which has the effect of "eviscerating foreign investment". ${ }^{84}$

This interpretation might be seen as the most absolute conception of the Police Powers Doctrine. No mention is made to proportionality, reasonableness,

80 PELLET, Alain. Police Powers of the State's Right to Regulate. In: KINNEAR, Meg; FISCHER, Geraldine (eds). Building International Investment Law: The First 50 Years of ICSID. Alphen aan den Rijn, Wolters Kluwer, Dec. 2015. p. 447-462. p.449.

81 RANJAN, Prabash. Police Powers, indirect expropriation in international investment law, and article 31(3)(c) of the VCLT: A critique of Philip Morris v Uruguay. Asian Journal of International Law, Cambridge, v. 9, n. 1, p.98-124, Sep. 2019.

82 Saluka Investments BV v Czech Republic, UNCITRAL, Partial Award 17 March 2006. para. 254.

83 Saluka Investments BV v Czech Republic, UNCITRAL, Partial Award 17 March 2006. para. 276.

84 Saluka Investments BV v Cqech Republic, UNCITRAL, Partial Award 17 March 2006. para. 276. 
specific commitments, or the quantum of damages. ${ }^{85}$ If "evisceration" is a synonym for "substantial deprivation" or expropriation amounting to direct expropriation, then the only boundaries set to Police Powers Doctrine are the discriminatory character and the bona fide purposes, i.e., the demonstration of a rational public purpose. ${ }^{86}$ This rule has been deemed eliciting negative ramifications to the predictability of the international investment system for investors. This may be the reason why later tribunals while referring to the Methanex award, rendered the application of the Doctrine more flexible and subject to a more fact-based approach by arbitrators.

Third, in the Chemtura v. Canada, ${ }^{87}$ the Tribunal used a singular approach to apply the Police Powers Doctrine to a ban imposed by the Canadian Pesticide Management Regulation Agency on a pesticide allegedly causing damages to human health and the environment. The US company manufacturing the pesticide challenged the new regulation under Article 1110 of the NAFTA and its expropriation clause. Following, the arbitral tribunal defined Police Powers as follows:

\begin{abstract}
"Irrespective of the existence of a contractual deprivation, the Tribunal considers in any event that the measures challenged by the Claimant constituted a valid exercise of the Respondent's Police Powers $(. .$.$) in a non-discriminatory manner, mo-$ tivated by the increasing awareness of the dangers presented by lindane for human health and the environment. A measure adopted under such circumstances is a valid exercise of the State's Police Powers and, as a result, does not constitute an expropriation. (emphasis added)" $" 88$
\end{abstract}

The Chemtura interpretation retrieves the conditions of absence of discrimination and of "deprivation", which is closely related to the concept of economic damage, from past jurisprudence. It can be argued however that the tribunal introduces a test of reasonableness and scientific knowledge. By stating that the re-

\footnotetext{
85 KURTZ, Jürgen. Building Legitimacy Through Interpretation in Investor-State Arbitration: On Consistency, Coherence and Identification of Applicable Law. In: DOUGLAS, Zachary, PAUWELYN, Joost and VIÑUALES, Jorge E. (eds). Foundations of International Investment Law. Oxford: Oxford University Press, 2014.

86 RANJAN, Prabash. Police Powers, indirect expropriation in international investment law, and article 31(3)(c) of the VCLT: A critique of Philip Morris v Uruguay. Asian Journal of International Law, place, v. 9, n. 1, p.98-124, Sep. 2019.

87 Chemtura Corporation v Government of Canada, UNCITRAL, Award of 2 August 2010.

88 Chemtura Corporation v Government of Canada, UNCITRAL, Award of 2 August 2010. para. 266.
}

gulations were "motivated" by the human health and environmental risks posed by 'lindane', the arbitrators seem to conclude that the measure was "a contribution to the public objective". Nevertheless, the "proportionality" of the measure is absent from the reasoning of the arbitrators and explicitly rejects the possibility that "contractual deprivation" could set a limit to the use of the Doctrine, let alone the State's right to regulate. The tribunal thus elaborates a balanced assessment, relying on the scientific evidence, good faith, and reasonableness. The absence of a proportionality test may be justified by the facts of the case, and the specific scientific evidence examined by the tribunal.

Fourth, the Tecmed v. Mexico award ${ }^{89}$ introduced the idea of "reasonable relationship of proportionality". First stating that there existed an indisputable "principle" under international law, "that the State's exercise of its sovereign power within the framework of its Police Powers may cause economic damage to those subject to its powers as administrator without entitling them to any compensation whatsoever." 90 The Tribunal then disputed the assumption that only domestic tribunals or domestic laws may determine whether the exercise of such power is legitimate. ${ }^{91}$ On the contrary, the tribunal adopted a proportionality analysis, to state that even if the measures taken by the Respondent State are in accordance with its domestic laws, this does not mean that they conform to the Agreement or international law. Arguing this, the tribunal refers to the jurisprudence of the International Court of Justice ${ }^{92}$ and Judge James Crawford. ${ }^{93}$ According to the latter: "An Act of State must be characterized as internationally wrongful if it constitutes a breach of an international obligation, even if the act does not contravene the State's internal law - even if under that law, the State was bound to act that way." $" 94$

89 Técnicas Medioambientales Tecmed, S.A. v The United Mexican States, (Award) (ICSID Arbitral Tribunal, case No. ARB (AF)/00/02, 29 May 2003)

90 Técnicas Medioambientales Tecmed, S.A. v The United Mexican States, (Award) (ICSID Arbitral Tribunal, case No. ARB (AF)/00/02, 29 May 2003). para 119.

${ }_{91}$ Técnicas Medioambientales Tecmed, S.A. v The United Mexican States, (Award) (ICSID Arbitral Tribunal, case No. ARB (AF)/00/02, 29 May 2003). para 120.

92 Electronica Sicula S.p.A. (ELSI) (United States of America v Italy) [1989], (Judgement) ICJ Rep 73; Marvin (n 59), p.26, 78.

93 Técnicas Medioambientales Tecmed, S.A. v The United Mexican States, (Award) (ICSID Arbitral Tribunal, case No. ARB (AF)/00/02, 29 May 2003). para. 221.

94 CRAWFORD, James. The International Law Commission's Articles 
Most importantly, the tribunal adds that, even if a measure is beneficial to the public at large, if its economic impact on the financial position of the investor is sufficient to amount to full deprivation (neutralize the full value of the investment), the measure might still be considered expropriatory. ${ }^{95}$

Thus, according to this interpretation, to find out "whether actions or measures are proportional to the public interest presumably protected thereby and to the protection legally granted to investments, taking into account that the significance of such impact has a key role upon deciding the proportionality". ${ }^{96}$ The tribunal introduces the concept of proportionality into the assessment of indirect expropriation. To that extent, it refers to the jurisprudence of the European Court of Justice on the 'European concept ${ }^{97}$ of proportionality. ${ }^{98}$

Moreover, it accepts that the regulatory measure will not be considered as expropriatory if a "reasonable relationship of proportionality" and "could be established between the charge or weight imposed by the measure on foreign investment and the aim that the impugned measure seeks to achieve." ${ }^{\prime 99}$ The reasonableness, ${ }^{100}$ according to which a tribunal should assess the contribution of a policy to the objective, combined ('in relationship') with the notion of proportionality, enhances

on State Responsibility. Cambridge: Cambridge University Press, 2002.

95 Técnicas Medioambientales Tecmed, S.A. v The United Mexican States, (Award) (ICSID Arbitral Tribunal, case No. ARB (AF)/00/02, 29 May 2003). para. 221.

96 Técnicas Medioambientales Tecmed, S.A. v The United Mexican States, (Award) (ICSID Arbitral Tribunal, case No. ARB (AF)/00/02, 29 May 2003). para. 222.

${ }_{97}$ TITI, Catharine. Police Powers Doctrine And International Investment Law. In: GATTINI, Andrea, TANZI, Attila and FONTANELLI, Filippo (eds.). General Principles Of Law And International Investment Arbitration, Leiden, the Netherlands: Brill Nijhoff, 2018.

98 Matos e Silva, Lda., and Others v Portugal, European Court of Human Rights, Judgement of 16 September 1996, 92. p. 19.

99 RANJAN, Prabash. Police Powers, indirect expropriation in international investment law, and article 31(3)(c) of the VCLT: A critique of Philip Morris v Uruguay. Asian Journal of International Law, place, v. 9, n. 1, p.98-124, Sep. 2019.

100 NEWCOMBE, Andrew and PARADELL, Lluis. Law and Practice of Investment Treaties: Standards of Treatment. Alphen Aan Den Rijn, The Netherlands: Kluwer International Law, 2009; see also ROBERTS, Anthea. The Next Battleground: Standards of Review in Investment Treaty Arbitration. In: VAN DEN BERG, Albert Jan (ed). Arbitration - The Next Fifty Years. Alphen Aan Den Rijn, The Netherlands: Kluwer Law International, 2012, p. 170-180; NEWCOMBE, Andrew. The Boundaries of Regulatory Expropriation in International Law. In: KAHN, Philippe and WÄLDE Thomas W (eds). New Aspects of International Investment Law. Leiden: Martinus Nijhoff Publishers, 2007. the level of scrutiny and discretion accorded to the tribunal. This introduction of a 'reasonable relationship of proportionality' established in 2003, could have disappeared to the benefit of the Methanex, Saluka or Chemtura rules. It nonetheless was a key part of the reasoning in Philip Morris in 2016. ${ }^{101}$

In the Philip Morris v. Uruguay award, this "reasonable relationship of proportionality" was retrieved. First, the tribunal applied a first test that assessed if the measure did have the effect to deprive the Investor of its Investment. Second, the arbitrators applied the Police Powers Doctrine as a customary law with a test that resembles the Tecmed's "reasonable relationship of proportionality". Thus, the tribunal focussed on the sole effect Doctrine and the Police Powers test to assess whether the regulation taken by the State amounted to indirect expropriation. ${ }^{102}$

The decision against the tobacco company Philipp Morris in Philipp Morris v The Republic of Uruguay reflects the current dispute on the Doctrine's interpretation in the field of expropriation. Moreover, we can argue that the tribunal adopted a particularly fact-based analysis that influenced its assessment of the Police Powers Doctrine. Indeed, the investor's claim was rejected upon two grounds. First, it was decided that the effect of the regulatory measure taken by the State did not amount to a substantial deprivation of the investment. Only then after, did the tribunal analysed whether the State's measure fell within the Police Powers Doctrine. It could therefore be argued that the application of the Police Powers Doctrine was more an obiter dictum that grants arbitral tribunal the powers to review a State's measure, than a decisive interpretation of the measure at stake and its impact on the investor's claim.

In conclusion, the threshold and application of the Doctrine in a specific case, might considerably depend on the set of relevant facts given to the arbitrators, as

101 REMOUNDO, Kyriaki and KOUNDOURI, Phoebe. Environmental Effects on Public Health: An Economic Perspective. International Journal of Environmental Research and Public Health, Basel, v. 6, n. 8, p. 2160-2178, Jul. 2009; JOHNSON, Hope. Investor-State Dispute Settlement and Tobacco Control: Implications For Non-Communicable Diseases Prevention And ConsumptionControl Measures. QUT Law Review, Queensland, v. 17, n. 2, p. 102-130, Nov. 2014.

102 RANJAN, Prabash. Police Powers, indirect expropriation in international investment law, and article 31(3)(c) of the VCLT: A critique of Philip Morris v Uruguay. Asian Journal of International Law, place, v. 9, n. 1, p.98-124, Sep. 2019. 
well as to the judgment of arbitrators on the topic of the bona fide measures adopted by States.

\section{Application of the Police Powers Doctrine to Covid-19 measures}

As we have demonstrated above, to qualify under the Police Powers Doctrine a policy measure might need to comply with the requirements of public interest, good faith, due process, non-discrimination, legitimate expectation, and a form of proportionality or reasonableness. To address the sanitary crisis, States have adopted a series of measures to differing degrees, ranging from indirect expropriations to discriminative behaviors. These requirements will thus be applied to the measures taken during the Covid-19 sanitary crisis.

The first two requirements - public interest and good faith - seem most evident in the assessment of a measure taken to protect the public health of the State's population. As shown above, the threshold to meet the requirements of public interest and good faith are the lowest in the standard of review applied by arbitral tribunals. The pandemic is a global phenomenon which has received widespread scientific attention. This has undoubtedly generated a consensus as to the necessity to take measures to counter the spread of Covid-19. Thus, a policy measure adopted to halt the spread of the virus might easily qualify as meeting the public interest requirement. Since good faith is largely dependent on the state's own evaluation of the sanitary crisis, this requirement appears likely to be met.

Second, in terms of due process, the sanitary crisis has forced States to act fast and with improper knowledge, risking a breach of the transparency doctrine. A measure taken in an emergency state in the wake of the pandemic might have thus lacked the common standards applied to due process. ${ }^{103}$ However, the requirement of due process constitutes a low standard to meet when considering the expropriation clause. Thus, it might not constitute an obstacle to qualify a measure as an exercise of the State's police powers for the purpose of the

\footnotetext{
103 REINISCH, August. The Rule of Law in International Investment Arbitration. In: PAZARTZIS, Photini and GAVOUNEL, Maria (eds). Reconceptualizing the Rule of Law in Global Governance, Resources, Investment and Trade. Oxford: Hart Publishing, 2016.
}

expropriation clause. ${ }^{104}$ Practically, a tribunal might assess whether the State has consulted stakeholders when adopting policy options.

Third, the requirement of non-discrimination demands an exhaustive case-by-case analysis. When considering policies such as "social distancing" or the closure of certain businesses incapable of operating remotely, the States will not have acted in a discriminative way prima facie. On the contrary, the Peruvian emergency measure suspending the collection of toll fees on the country's road network are likely to fall under the discrimination assessment. ${ }^{105}$ Similarly, the measure taken by Mexico to close US owned plants allegedly following the refusal to sell ventilators, are unlikely to respect the non-discrimination requirement. ${ }^{106}$

Fourth, legitimate expectations might play an unexpected role in the assessment of whether the liability of the State is avoided. ${ }^{107}$ Indeed, if the State has given specific insurances to a foreign Investor, this might influence the arbitral tribunal in its analysis of the fair and equitable treatment, but also, as demonstrated in earlier case-law, in its assessment of the police powers Doctrine. While this does not constitute a sound interpretation of the expropriation clause or of the Doctrine; States shall be aware of the potential influence of the legitimate expectation doctrine on the finding of a police powers measure in a specific case.

Finally, the proportionality and reasonableness of a policy measure might develop into the most disputed factors of the analysis. Whether the measure qualifies as exempting the liability of the State from indirect

104 But might not avoid the liability of the State under the Fair and Equitable clause. On a contrary opinion of this paper to the role of due process in the assessment of the legality of an indirect expropriation and qualification under the police powers doctrine, see SLOANE, Robert D. and REISMAN, W. Michael. Indirect Expropriation and its Valuation in the Bit Generation. British Yearbook of International Law, Oxford, v. 75, p. 115-150, 2004.

105 MORING, Crowell. Client Alert, COVID-19: The Latin America Perspective II - Argentina and Peru. Crowell, April 2020. Available at: https://www.crowell.com/NewsEvents/AlertsNewsletters/all/ COVID-19-The-Latin-America-Perspective-II-Argentina-and-Peru ?fbclid=IwAR39DYXyJZdrjenvPyScJIrd-OjnTXfbnYHL23HlciO nth3R_0oVVCkOIl8 Accessed on: 25 February 2021.

106 ASSOCIATED PRESS. Mexico Closes US Owned Plant for Refusal to Sell Ventilators US News, April 2020. Available at: https://www.usnews.com/news/best-states/minnesota/articles/2020-04-10/mexico-closes-us-owned-plant-forrefusal-to-sell-ventilators Accessed on: 25 February 2021.

107 AHMED, Farrah and PERRY, Adam. The Coherence of the Doctrine of Legitimate Expectations. Cambridge Law Journal, Cambridge, v. 73, n. 1, p. 61-85, Mar. 2014. 
expropriation, will likely depend on the threshold of proportionality adopted by the arbitral tribunal. Here, the factors of a specific case might influence which threshold the tribunal could apply. As a general overview, measures such as social distancing appear as building consensus among the scientific community, so that its implementation could easily fulfill the most demanding requirements of proportionality. On the other hand, more disruptive measures, such as the obligation to companies to manufacture ventilators and masks in the US, the nationalization of private hospitals in Spain and seizure of medical masks by France, will require a fact-based analysis. This analysis will weigh whether their adoption respects the "reasonable relationship of proportionality" 108 stated out in Tecmed and Philip Morris. A relationship that "could be established between the charge or weight imposed by the measure on foreign investment and the aim that the impugned measure seeks to achieve".

Last, it is worth recalling the 1903 US Bischoff Case, ${ }^{109}$ in which the claimant had its carriage seized by law enforcement authorities based on (incorrect) information that the carriage had carried persons afflicted with smallpox. When the carriage was returned damaged, the claimant brought proceedings for damages before the German-Venezuelan Mixed Claims Commission. The Commission held that 'during the epidemic of an infectious disease there can be no liability for the reasonable exercise of police power, even though a mistake is made'. ${ }^{110}$ Nevertheless, the tribunal did award damages in this case, on the ground that the authorities returned the carriage to the claimant after an unreasonable delay.

\section{Conclusion}

Even in the absence of an express provision under international investment law, non-discriminatory measures of a general application aiming at safeguarding public health are generally considered consistent with

\footnotetext{
108 RANJAN, Prabash. Police Powers, indirect expropriation in international investment law, and article 31(3)(c) of the VCLT: A critique of Philip Morris v Uruguay. Asian Journal of International Law, place, v. 9, n. 1, p.98-124, Sep. 2019.

109 Germany-Venezuela Mixed Claims Commission (1903) reprinted in (1960) 10 RIAA 420

110 Bischoff Case (1903) reprinted in (1960) 10 RIAA 420.
}

States' international obligations. This means that the appropriate use of State police powers would ordinarily not give rise to State liability under international law, even if foreign investors have been negatively affected. As demonstrated in this paper, the Doctrine of Police Powers has nevertheless been subject to different interpretations as to its scope, integration, customary status, and conditions of application. ${ }^{11}$

The most recent decision on the Police Powers Doctrine in the Magyar award acknowledges that a line of case law has been developed, consisting of "regulatory measures aimed at abating threats that the investor's activities may pose to public health, environment or public order". ${ }^{112}$ We thus argued that the customary nature of the Doctrine is established, and that the protection of public health is situated within the scope of the police powers of states.

The paper then argued for an integration of the Doctrine respectful of the Vienna Convention on the Law of treaties. We argued that Doctrine should not be integrated through an extensive interpretation of the treaty's words (Article 31(1) VCLT) if the treaty does not refer expressly to an exemption to the expropriation clause. It was argued that a tribunal would do an adequate integration of the Doctrine if the treaty expressly referred to it, or when the measure at stake makes the use of the Doctrine relevant and necessary under Article 31(3)(c) of the VCLT.

The general requirements put forth by arbitral tribunals for the application of police powers doctrine were then examined. The conclusion was that the threshold and application of the Doctrine and its requirement varied considerably in the case-law, so that it could be argued that the decision of arbitrators depends on the set of relevant facts, as well as to the judgment of arbitrators on the topic of the bona fide measures adopted by States.

Finally, we demonstrated that the question of whether a measure crosses the line separating non-compensable regulatory activity from expropriation must be assessed in light of all the circumstances. This principle holds true for measures adopted during the Covid-19

\footnotetext{
111 WAELDE, Thomas; KOLO, Abba. Environmental Regulation, Investment Protection and "Regulatory Taking" in International Law. International and Comparative Law Quarterly, Cambridge, v.50, n.4, p.811-848, Oct. 2008.

112 Magyar Farming v Hungary, Award, 13 November 2019. para. 302.
} 
pandemic. It is nevertheless argued that most of the measures adopted by States should, prima facie, qualify under the Police Powers Doctrine, on the grounds of public interest, good faith, and non-discrimination. The paper argued that the character of the pandemic, as a sudden phenomenon eliciting consensus among the scientific community as to the necessity of adoption of measures, should lower the standard of review in the assessment of the other requirements - such as legitimate expectations, due process and proportionality.

\section{References}

ALVAREZ, José E. The search for Objectivity: The Use of Experts in Philip Morris v Uruguay. Journal of International Dispute Settlement, Oxford, v. 9, n. 3, p. 411422, Apr. 2018.

ALTERMAN, Rachelle; BALLA Evangelina. Takings International: A Comparative Perspective on Land Use Regulations and Compensation Rights. Chicago: American Bar Association Section of State and Local Government Law, 2010.

ASCENSIO, Hervé. Article 31 of the Vienna Conventions on the Law of Treaties and International Investment Law. ICSID Review, Oxford, v. 31, n. 2, p.366387, Jun. 2016.

ASSOCIATED PRESS. Mexico Closes US Owned Plant for Refusal to Sell Ventilators US News, April 2020. Available at: https://www.usnews.com/news/ best-states/minnesota/articles/2020-04-10/mexicocloses-us-owned-plant-for-refusal-to-sell-ventilators Accessed on: 25 February 2021.

BAUGHEN, Simon. Expropriation and Environmental Regulation: The lessons of NAFTA Chapter Eleven, Journal of Environmental Law, Oxford, v. 18, n. 2, p.207228, Jan. 2006.

BERNASCONI-OSTERWALDER,

Nathalie; BREWIN, Sarah; MAINA, Nyaguthii. Commentary: Protecting Against Investor-State Claims Amidst COVID-19: A call to action for governments. IISD, April 2020. Available at: https://www.iisd.org/system/files/ publications/investor-state-claims-covid-19.pdf. Accessed on: 31 Mar. 2021.
CHENG, Bin. General Principles of Law as applied by International Courts and Tribunals. Cambridge: Cambridge University Press, 2006.

CHRISTIE, George. What constitutes a Taking of Property Under International Law? British Yearbook of International Law, Oxford, v.38, p.307-338, 331-32, 1962.

COLUMBIA CENTRE ON SUSTAINABLE INVESTMENT. Call for ISDS Moratorium During COVID-19 Crisis and Response. May 2020. Available at: http: / ccsi.columbia.edu/2020/05/05/isds-moratorium-during-covid-19/ Accessed on: 31 Mar. 2021.

DIAMOND, Nicholas; DUGGAL, Kabir. 2020 in Review: The Pandemic, Investment Treaty Arbitration, and Human Rights. Kluwer Arbitration Blog. Jan. 2021. Available at: http://arbitrationblog.kluwerarbitration. com/2021/01/23/2020-in-review-the-pandemic-investment-treaty-arbitration-and-human-rights/ Accessed on: 31 Mar. 2021.

GAILLARD, Emmanuel. 2018 Lalive Lecture "The Myth of Harmony in International Arbitration". ICSID Review - Foreign Investment Law Journal, Oxford, v. 34, n. 3 , p. 553-568, Apr. 2018.

GALVA, Jorge; ATCHISON Christopher; LEVEY Samuel. Public Health Strategy and the Police Powers of the State. Public Health Report, Washington D.C., v. 120, n. 1, p. 20-27, 2005.

GONZALES, Elizabeth et al. The Coronavirus in Latin America. America Society Council of the Americas, Feb. 2021. Available at: https://www.as-coa.org/articles/ coronavirus-latin-america. Accessed on: 31 Mar. 2021.

GUDOFSKY, Jason. Shedding Light on Article 1110 of the North American Free Trade Agreement (NAFTA) Concerning Expropriations: An Environmental Case Study. Northwestern Journal of International Law and Business, Chicago, v. 21, n. 1, p. 243-316, Jan. 2000.

HARRIS, Troy L. Customary International Arbitration Law. American Review of International Arbitration, New York, v. 24, n. 2, p. 245-270, Aug. 2013.

HENCKELS, Caroline. Indirect Expropriation and the Right to Regulate: Revisiting Proportionality Analysis and the Standard of Review in Investor-State Arbitration. Journal of International Economic Law, Oxford, v. 15, n.1, p. 223-255, Mar. 2012. 
HERZ, John. Expropriation of Foreign Property. The American Journal of International Law, Cambridge, v. 35, p. 243-262, Apr. 1941.

HIGGINS, Rosalyn. The Taking of Property and the State: Recent Developments. Leiden: Martinus Nijhoff, 1982.

INTERNATIONAL MONETARY FUND. 'The Economic Effects of COVID-19 Containment Measures' IMF Working Papers No. 20/158. Jul. 2020. Available at: https://www.imf.org/en/Publications/WP/Issues/2020/08/07/The-Economic-Effects-of-COVID19-Containment-Measures-49571. Accessed on: 31 Mar. 2021.

JOHNSON, Hope. Investor-State Dispute Settlement and Tobacco Control: Implications For Non-Communicable Diseases Prevention And Consumption-Control Measures. QUT Law Review, Queensland, v. 17, n. 2, p. 102-130, Nov. 2014.

KURTZ, Jürgen. Building Legitimacy Through Interpretation in Investor-State Arbitration: On Consistency, Coherence and Identification of Applicable Law. In: DOUGLAS, Zachary, PAUWELYN, Joost and VIÑUALES, Jorge E. (eds). Foundations of International Investment Law. Oxford: Oxford University Press, 2014.

LEGARRE, Santiago. The Historical Background of the Police Power. University of Pennsylvania Journal of Constitutional Law, Philadelphia, v. 9, p. 745-796, Feb. 2007.

MARTINEZ-FrAGA, Pedro; REETZ, Ryan. Public Purpose in International Law, Rethinking Regulatory Sovereignty in the Global Era. New York: Cambridge University Press, 2015.

MITCHELL, Andrew D., HEATON, David, and HENCKELS, Caroline. Non-Discrimination and the Role of Regulatory Purpose in International Trade and Investment Law. Cheltenham: Edward Elgar, 2016.

MITCHELL, Kate. Accommodating the Public Interest in International Investment Treaties: Police Powers, Expropriation and Treaty Interpretation. 2014. $121 \mathrm{f}$. Thesis (Masters) - MPhil, University of Oxford, Oxford, 2014.

MORING, Crowell. Client Alert, COVID-19: The Latin America Perspective II - Argentina and Peru. Crowell, April 2020. Available at: https://www.crowell.com/ NewsEvents/AlertsNewsletters/all/COVID-19-TheLatin-America-Perspective-II-Argentina-and-Peru?fbcli d=IwAR39DYXyJZdrjenvPyScJIrd-OjnTXfbnYHL23
HlciOnth3R_0oVVCkOIl8 Accessed on: 25 February 2021.

NEWCOMBE, Andrew. The Boundaries of Regulatory Expropriation in International Law. In: KAHN, Philippe and WÄLDE Thomas W (eds). New Aspects of International Investment Law. Leiden: Martinus Nijhoff Publishers, 2007.

NEWCOMBE, Andrew and PARADELL, Lluis. Law and Practice of Investment Treaties: Standards of Treatment. Alphen Aan Den Rijn, The Netherlands: Kluwer International Law, 2009.

PAPARINSKIS, Martin. Investment Treaty Interpretation and Customary Investment Law: Preliminary Remarks. In: BROWN, Chester; MILES, Kate (eds.). Evolution in Investment Treaty Law and Arbitration. Cambridge: Cambridge University Press, 2011. p. 65-78. PELLET, Alain. Police Powers of the State's Right to Regulate. In: KINNEAR, Meg; FISCHER, Geraldine (eds). Building International Investment Law: The First 50 Years of ICSID. Alphen aan den Rijn, Wolters Kluwer, Dec. 2015. p. 447-462.

RANJAN, Prabash. Police Powers, indirect expropriation in international investment law, and article 31(3)(c) of the VCLT: A critique of Philip Morris v Uruguay. Asian Journal of International Law, place, v. 9, n. 1, p.98124, Sep. 2019

REINISCH, August. The Rule of Law in International Investment Arbitration. In: PAZARTZIS, Photini and GAVOUNEL, Maria (eds). Reconceptualizing the Rule of Law in Global Governance, Resources, Investment and Trade. Oxford: Hart Publishing, 2016.

REMOUNDO, Kyriaki and KOUNDOURI, Phoebe. Environmental Effects on Public Health: An Economic Perspective. International Journal of Environmental Research and Public Health, Basel, v. 6, n. 8, p. 2160-2178, Jul. 2009.

REYNOLDS Glenn; KOPEL David. The Evolving Police Power: Some Observations for a New Century. Hastings Constitutional Law Quarterly, San Fransisco, v.27, n.3, p. 511-538, Jan. 2000.

ROBERTS, Anthea. The Next Battleground: Standards of Review in Investment Treaty Arbitration. In: VAN DEN BERG, Albert Jan (ed). Arbitration - The Next Fifty Years. Alphen Aan Den Rijn, The Netherlands: Kluwer Law International, 2012, p. 170-180. 
SANDERSON, Cosmo, Peru warned of potential ICSID claims over covid-19 measures. Latin Lanyer, Apr 2020. Available at: https://latinlawyer.com/article/1225491/peru-warned-of-potential-icsid-claimsover-covid-19-measures Accessed on: 31 Mar. 2021.

SLOANE, Robert D. and REISMAN, W. Michael. Indirect Expropriation and its Valuation in the Bit Generation. British Yearbook of International Law, Oxford, v. 75, p. 115-150, 2004.

SMITH Adam. Lectures on Justice, Police, Revenue and Arms, delivered in the University of Glasgow by Adam Smith: Reported by a Student in 1763 and edited with an Introduction and notes by Edwin Cannan. Oxford: Clarendon Press, 1869.

SIMMA, Bruno. Foreign Investment Arbitration: A Place for Human Rights. International and Comparative Law Quarterly, place, v. 60, n. 3, p.573-596, Jul. 2011.

TITI, Catharine. International Investment Law and the European Union: Towards a New Generation of International Investment Agreements. European Journal of International Law, Oxford, v. 26, n. 3, p. 639-661, Aug. 2015.

TITI, Catherine. The Evolution of Substantive Investment Protections in Recent Trade and Investment Treaties, 2018. Available at: https://e15initiative.org/ wp-content/uploads/2015/09/ictsd_-_the_evolution_ of_substantive_investment_protections_in_recent_trade_and_investment_treaties_-_titi.pdf Accessed on 31 March 2021.

TITI, Catherine. Police Powers Doctrine and International Investment Law. In; FONTANELLI Filippo; GATTINI Andrea; TANZI Attila (eds.). General Principles of Law and International Investment Arbitration. Leiden: Brill, 2018. p.323-343.

UNCTAD INVESTMENT POLICY HUB. Investment Policy Monitor: Special Issue - Investment Policy Responses to the COVID-19 Pandemic. May 2020. Available at: https://unctad.org/system/files/ official-document/diaepcbinf2020d3_en.pdf Accessed on: 31 Mar. 2021.

VIÑUALES, Jorge E. Sovereignty in Foreign Investment Law. In: DOUGLAS, Zachary, PAUWELYN, Joost, and VIÑUALES, Jorge E. (eds). Foundations of International Investment Law. Oxford: Oxford University Press, 2014, Chapter 12, 340-342.
WAELDE, Thomas; KOLO, Abba. Environmental Regulation, Investment Protection and "Regulatory Taking" in International Law. International and Comparative Law Quarterly, Cambridge, v.50, n.4, p.811-848, Oct. 2008.

ZAMIR, Noam. The Police Powers doctrine in international investment law. Manchester Journal of International Economic Law, Manchester, v.14, n.3, p.318-337, Dec. 2017.

\section{Cases (if necessary)}

ADC Affiliate Ltd. and ADC \& ADMC Management Ltd $\mathrm{v}$ Republic of Hungary, ICSID Case No. ARB/03/16, Award of 2 October 2006.

Aguas del Tunari SA v. Bolivia, ICSID Case No. $\mathrm{ARB} / 02 / 3$, Decision on Respondent's Objections to Jurisdiction of 21 October 2005.

AWG Group Ltd. v The Argentine Republic, UNCITRAL, Decision on Liability, 30 July 2010.

Azurix Corp v The Argentine Republic, ICSID Case No. ARB/01/12, Award of 14 July 2006.

BG Group plc v Argentina, UNCITRAL Arbitral Tribunal, Final Award of 24 December 2007.

Bywater Gauff (Tanzania) Ltd v. Tanzania, ICSID Case No. ARB/05/22, Award of 24 July 2004.

Chemtura Corporation v Government of Canada, UNCITRAL, Award of 2 August 2010.

CMS Gas Transmission Co v Argentina, ICSID Case No. ARB/01/8, Award of 12 May 2005.

Compañía del Desarrollo de Santa Elena SA v The Republic of Costa Rica, ICSID ARB/96/1, Final Award of 17 February 2000.

Continental Casualty Co v. Argentina, ICSID Case No. ARB/03/9, Award of 5 September 2008.

Cyprus Popular Bank Public Co Ltd v. Hellenic Republic, ICSID Case No. ARB/14/16, Decision on Jurisdiction and Liability of 8 January 2019.

Daimler Financial Services AG v. Argentina, ICSID Case No. ARB/05/1, Award of 22 October 2012.

Enron Corporation and Ponderosa Assets, L.P. v Argentina, ICSID Case no. ARB/01/3, Award of May 22, 2007. 
Electronica Sicula.S.p.A. (ELSI) (United States of America v Italy) [1989], (Judgement) ICJ Rep 73.

El Paso Energy International Company $\mathrm{v}$ Argentine Republic, ICSID Case No. ARB/03/15, Award of 31 October 2011.

Dispute regarding Navigational and Related Rights (Costa Rica v. Nicaragua), International Court of Justice, Judgement Report of 13 July 2009.

LG\&E Energy Corp, LG\&E Capital Corp, LG\&E International Inc v Argentina, ICSID Case No. ARB/02/1, Decision on Liability of 3 October 2006.

Generation Ukraine Inc. v Ukraine, ICSID Case No. ARB/00/9, Award of 16 December 2003.

Germany-Venezuela Mixed Claims Commission (1903) reprinted in (1960) 10 RIAA 420

Marvin Roy Feldman Karpa v United Mexican States, ICSID Case No ARB(AF)/99/1, Award of 16 December 2002.

Matos e Silva, Lda., and Others v. Portugal, European Court of Human Rights, Judgement of September 16 1996.

Methanex Corporation v United States of America, UNCITRAL, Final Award on Jurisdiction and the Merits, 3 August 2005, RL-109

National Grid PLC v. Argentina, UNCITRAL Arbitral Tribunal, Award of 3 November 2008.

Magyar Farming v Hungary, Award, 13 November 2019

Philip Morris Brands Sárl, Philip Morris Products SA and Abal Hermanos SA v Oriental

Republic of Uruguay, ICSID Case No. ARB/10/7, Award of 8 July 2016.

Poitova and ISTROK4PITAL SE v. Hellenic Republic, ICSID Case No. ARB/I13/8, Award of 9 April 2015.

Pope \& Talbot Inc v The Government of Canada, UNCITRAL, Interim Award of 26 June 2000.

Saluka Investments BV v Czech Republic, UNCITRAL, Partial Award 17 March 2006.

S.D. Myers Inc. v Canada, UNCITRAL, First Partial Award ("Merits Award") of 13 November 2000.

Sedco Inc. v. National Iranian Oil Company and the Islamic Republic of Iran, IUSCT Case Nos. 128 and
129, Interlocutory Award (No. ITL 55-129-3) of 17 Sept 1985.

Sempra Energy International v Argentina, ICSID Case no. ARB/02/16, Award of September 28, 2007.

Suez, Sociedad General de Aguas de Barcelona SA, InterAguas Servicios Integrales del Aguas

SA v Argentina (Award) (ICSID Arbitral Tribunal, Case No. ARB/03/17, 30 July 2010).

Técnicas Medioambientales Tecmed SA v United Mexican States (Award), ICSID Case No. ARB(AF)/00/2, Award of 29 May 2003.

Teleanor v Hungary, ICSID Case No. ARB/04/15, Award, 13 September 2006.

Veteran Petroleum Ltd $\mathrm{v}$ The Russian Federation, UNCITRAL PCA Case No. 2005-05/AA228, Interim Award, 30 November 2009. 
Para publicar na Revista de Direito Internacional, acesse o endereço eletrônico www.rdi.uniceub.br ou www.brazilianjournal.org.

Observe as normas de publicação, para facilitar e agilizar o trabalho de edição. 